\title{
Sociobiology
}

RESEARCH ARTICLE - BEES

\section{Colony Development and Management of the Stingless Bee Scaptotrigona aff. postica (Apidae: Meliponini) Using Different Hive Models}

\author{
KL LEÃO ${ }^{1,2}$, ACM QUEIROZ $^{1}$, JC VEIGA $^{1,2}$, FAL CONTRERA ${ }^{2}$, GC VENTURIERI ${ }^{1}$ \\ 1 - Laboratório de Botânica - Embrapa Amazônia Oriental, Belém, Brazil \\ 2 - Universidade Federal do Pará, Belém, Brazil
}

\section{Article History \\ Edited by \\ Cândida M. L. Aguiar, UEFS, Brazil \\ Received 12 April 2016 \\ Initial acceptance 24 August 2016 \\ Final acceptance 16 November 2016 \\ Publication date 13 January 2017}

\section{Keywords}

Meliponiculture, standardized hives, stingless bee keeping, traditional hives.

\section{Corresponding author}

Kamila Leão Leão

Laboratório de Biologia de Abelhas

Instituto de Ciências Biológicas

Universidade Federal do Pará

Rua Augusto Corrêa, 01, Campus Básico

Guamá - CEP 66075-110 Belém-PA, Brasil

E-Mail: kamilabelha@gmail.com

\begin{abstract}
Meliponiculture, i.e. the management and propagation of stingless bees is an old activity throughout the Americas, and is widely practiced in Brazil. However, since stingless bee keeping is still not entirely standardized, studies are necessary to achieve a better practice. For example, the type of hive used in breeding must be designed for ease of colony management and be suitable for each species, as size, behavior, and nest architecture vary among the meliponines. This study tested the use of a vertical hive for breeding an undescribed species of the group Scaptotrigona postica (Latreille), Scaptotrigona aff. postica, and evaluated characteristics such as colony development and management in comparison to colonies bred using traditional horizontal hives. Ten colonies of the studied species were used, five transferred to each hive type tested. During six months, monthly observations of colony size, hive occupation and hive management were made. Brood comb area, contrasting with the other parameters, was approximately twice as large in vertical hives compared to horizontal hives. No significant difference in hive occupation was found among the tested models. Management differences were found among the two hive models, with vertical hives noted for having characteristics that facilitated colony inspection and division, causing only minor damage to the nest structures. Thus, the vertical model hive has clear advantages for the keeping of the studied Scaptotrigona species.
\end{abstract}

\section{Introduction}

The keeping of stingless bees (Tribe Meliponini), also known as meliponiculture, is an ancient practice in the Americas, carried out mainly by traditional communities (Villanueva-G et al., 2005; Cortopassi-Laurino et al., 2006). Generally, these communities still keep the stingless bees in a rudimentary way (Villanueva-G et al., 2005; Reyez-González et al., 2014), although recently, there have been attempts to enhance general bee keeping techniques and practices (Contrera et al., 2011; Venturieri et al., 2012).

It is possible to divide existing and the most frequently used hive models into two groups -horizontal and vertical hives. Horizontal hives are the most traditionally used in Brazil and Mesoamerica (Nogueira-Neto, 1997; Sommeijer, 1999; Cortopassi-Laurino et al., 2006). Horizontal hives are somewhat similar to hollow logs, placed horizontally (Vilamueva-G et al., 2005), and area common means of keeping stingless bee nests (i.e. "hobones": Quezada-Euán \& Gonzalez-Acereto, 1994, or "cortiços": Nogueira-Neto, 1997). Horizontal hives may be completely hollow, without any internal division, or more elaborate, with internal divisions to separate the nest from the honey storage space (Nogueira-Neto, 1997; Sommeijer, 1999).

The vertical, Baiano or Nordestino, Uberlândia, PNN, the UTOB and the INPA hive models are widely used in Brazil and in other countries as well, with or without local adaptations (Quezada-Euán \& Gonzalez-Acereto, 1994; Kerr et al., 1996; Nogueira-Neto, 1997; Sommeijer, 1999).The 
many hive models in the meliponiculture are directly linked to the vast diversity of stingless bee species present in these regions (Venturieri et al., 2012), and also based on personal and/or cultural preferences, as many beekeepers tend to create new hive models on their own even when the more known models (i.e. INPA, Embrapa, PNN, UTOB) are available.

The number of beekeepers using vertical hives is growing despite the horizontal models still being more widely used (Venturieri, 2008a). The vertical hive follows the natural brood comb pattern in tree trunks, divided into two main modules, the base chamber (to shelter the nest) and the upper chamber (to store honey and pollen; Portugal-Araújo, 1955). The creation of a specific honey storage compartment enables a faster and cleaner harvest, with minimum nest damage, the great advantage of this hive model (Venturieri et al., 2003; Venturieri, 2008a). However, actual comparisons on the advantages of each type of hive in regards to biological parameters, such as hive occupation and thermoregulation, as instance, are scarce, but in general point to that the type of hive that different species are bred result in clear differences in the health and development of the colonies (Quezada-Euán \& Gonzalez-Acereto, 1994).

Several bee species, mostly of the genus Melipona Illiger, are used in meliponiculture in Brazil and Mesoamerica (Nogueira-Neto, 1997; Reyez-González et al., 2014). The genus Scaptotrigona Moure is also an important genus for stingless bee keeping; well known for its populous colonies, and production of good quality honey in large quantities, in comparison to other meliponines (Cortopassi-Laurino et al., 2006; Reyez-González et al., 2014). A Scaptotrigona species from the group Scaptotrigona postica Latreille; thereafter called $S$. aff. postica (currently under review) that occurs in the state of Pará (Brazil) and commonly known as "canudo" (i.e. "straw") is a commonly kept stingless bee species in the Amazon region, as it has great honey production potential. In addition, this species may be of significant value for use in the pollination of native crop species (Venturieri et al., 2012), due to its tolerance of handling, populous colonies and the possibility to be multiplied on a large scale (Menezes et al., 2013).

Therefore, this study aimed to investigate the potential of vertical hives to breed $S$. aff. postica, assessing aspects such as biological adaptation and colony management, and comparing its performance to a horizontal hive model commonly used in the study region, as the optimization and standardization of management practices have the potential to increase productivity and income of beekeepers (Venturieri et al., 2003; Jaffé et al., 2015).

\section{Material and Methods}

\section{Study site and details of the population studied}

This study was carried out in the meliponary of the Botanical Department of Embrapa Amazônia Oriental $\left(1^{\circ} 26^{\prime} 11.52^{\prime \prime} \mathrm{S}, 48^{\circ} 26^{\prime} 35.50^{\prime \prime} \mathrm{W}\right)$, In the city of Belém, Pará,
Brazil, from August/2013 to January/2014. This sampling period comprised both dry (from August to November) and rainy periods (from December to January). The climate type in the area is $A f$ (Tropical-Rainforest) according to the updated Köppen classification (Peel et al., 2007). Embrapa is located in an environmental protection area (Utinga State Park), where managed and secondary forests and crops of several tropical, native and introduced species can be found.

Scaptotrigona aff. postica colonies from the municipality of Castanhal, Inhangapi, State of Pará, Brazil $\left(1^{\circ} 26^{\prime} 45.50^{\prime \prime} \mathrm{S} 47^{\circ} 52^{\prime} 56.14^{\prime \prime} \mathrm{O}\right)$ were used. These colonies were collected from tree hollows of areas used for agriculture and transferred to non-standardized hives by local beekeepers until they were transferred to the hives used in this study. The same care and procedures described by Nogueira-Neto (1997) were used during hive transfers. The bee colonies were fed monthly (about $30 \mathrm{ml} /$ colony $/$ month) with sugar syrup (60\%) offered in pots placed directly inside the nest, and arranged in individual shelters.

\section{The hives}

The vertical hive model proposed (Embrapa model) was compared to the horizontal hive, and based on the hive model used in Northern Brazil to breed bees from genus Melipona (Venturieri, 2008b). The vertical hive model, in turn, is based on the Portugal-Araújo (1955) hive model, modified by Venturieri (2008a) (Fig 1, Fig 2A). The vertical hive used in this study was made from wood and has square sections, measuring $25 \times 25 \times 34 \mathrm{~cm}$ and a $2.5 \mathrm{~cm}$ wide, segmented into four main parts: base chamber $(25 \times 25 \times 8 \mathrm{~cm}=3.2 \mathrm{~L})$, upper chamber $(25 \times 25 \times 8 \mathrm{~cm}=3.2 \mathrm{~L})$, honey super $(25 \times 25 \times 8 \mathrm{~cm})$ and cover $(25 \times 25 \times 2.5 \mathrm{~cm})$, as follows:

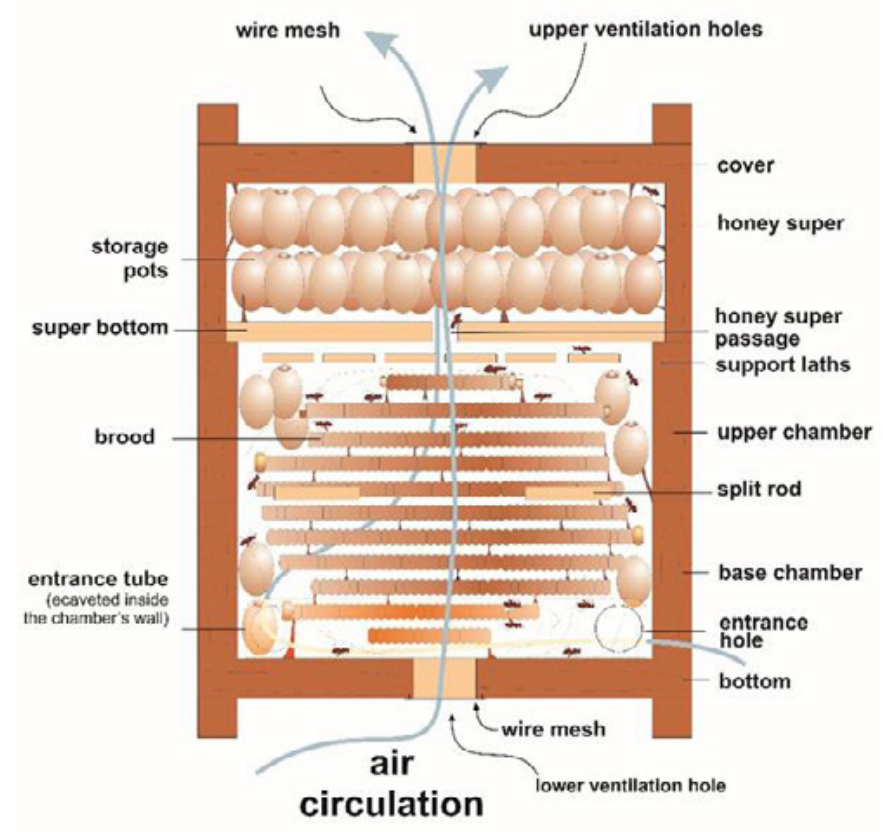

Fig 1.Vertical (Embrapa) hive model developed for housing Scaptotrigona aff. postica colonies. 
Base chamber: Area destined for the brood combs, shelter and food pots (honey and pollen) for the basic colony sustenance. A hole of $20 \mathrm{~mm}$ diameter in the frontal region enables bee entrance and exit. In the proposed hive model, an entrance corridor (20 $\mathrm{mm}$ wide and $25 \mathrm{~mm}$ high) runs within the wooden wall in the hive floor level, where bees circulate, to replicate the natural entrance tube formation of the studied species (Roubik, 2006). A hole of $31 \mathrm{~mm}$ diameter exists in the center of the base to enable air circulation within the hive. This orifice is sealed with a thin metal wire mesh to prevent the bees from making it a second entrance.

Upper chamber: Segment destined for nest expansion. There are two thick split rods $(3 \mathrm{~cm}$ wide, $1 \mathrm{~cm}$ thick and $20 \mathrm{~cm}$ long) on the base of the upper chamber, which helps support the brood combs and/or food pots and in the colony division process. Six thin support laths $(2 \mathrm{~cm}$ wide, $0.5 \mathrm{~cm}$ thick and $21 \mathrm{~cm}$ in length) are placed in the top to keep the brood combs from sticking on the lid or on the honey super.

Honey super: Area intended to store food pots for future harvesting. The honey super has the total internal volume of $6.4 \mathrm{~L}$, a $1 \mathrm{~cm}$ wide passage in its center bottom part for the access of the bees to the food pots. The honey super was not provided in this study, as the colonies were not used for honey production.

Cover: Upper end of the hive that has two $31 \mathrm{~mm}$ diameter holes in the middle region, to enable air circulation and supplementary feeding with bottles filled with sugar solution.

The horizontal ("cabocla") hives that were compared with the vertical hives had external dimensions of $49.5 \times 17$ $\mathrm{x} 17 \mathrm{~cm}, 2.5 \mathrm{~cm}$ thick wall, internal volume of $6.4 \mathrm{~L}$ and no internal divisions. Therefore, the two models had the same volume $(6.4 \mathrm{~L})$ and wall thickness, and varied only in regards to shape and internal divisions (i.e. the vertical hive did not include the supper; Fig 2). Both hive models were built using the timber of "Louro-canela" (Ocotea sp., Lauraceae), which is used for hive building due to its resistance to high levels of humidity, common in the Brazilian Amazon.

\section{Parameters analyzed}

Ten colonies of $S$. aff. postica were used, where five were transferred to the vertical hive and five to the horizontal. The nests began being evaluated 30 days after the colonies were transferred, to enable adaptation of the bees to the new hive. The evaluations were carried out considering the following parameters:

Nest components: 1.1 - Entrance tube size: The size and diameter (in millimeters) of the entrance tube - a structure considered as indicative of colonial strength and defense capacity (Couvillon et al., 2008) - were measured each month during six consecutive months for all colonies. For the analysis, in order to guarantee the independence of data, it was used the monthly difference of the measured values as independent variables. 1.2 - Number of brood combs: The brood combs of each colony were counted in non-consecutive months (e.g.: August-October-December/2014) in order to guarantee the independence of data. Since the brood combs develop over a 35days period, counting them in non-consecutive months ensured all brood combs would be new, and thus, considered independent in the analysis. 1.3 - Brood comb area: The first mature brood comb of each colony was measured with a caliper ruler, and its largest and smallest diameter (in millimeters) were recorded and multiplied to calculate the brood comb area (in $\mathrm{mm}^{2}$ : highest diameter $\mathrm{x}$ smallest diameter). This procedure was adopted to avoid an excessive handling of the colony; previous attempts to measure all the brood combs resulted in extensive damages and the subsequent weakening of the colonies. The same procedures to guarantee the independence of data regarding the number of brood combs were used for the brood comb area estimates.

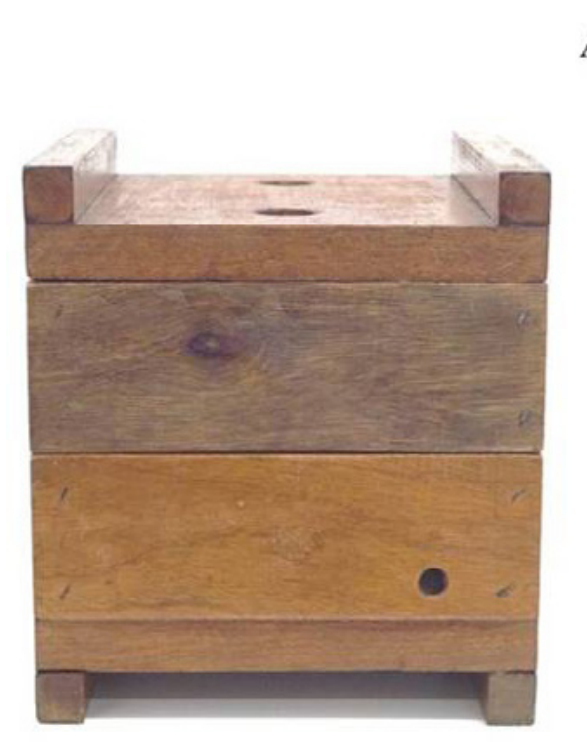

$\mathbf{A}$

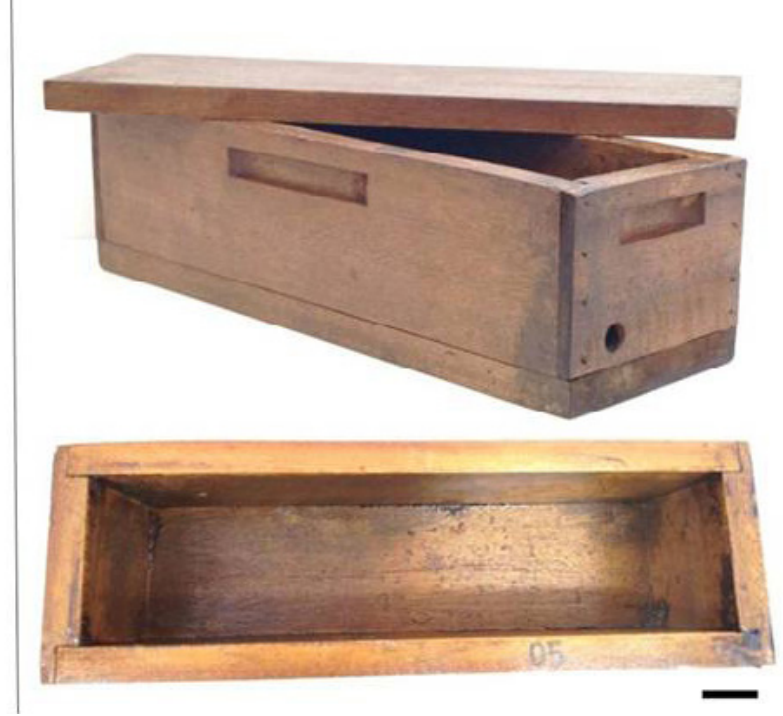

Fig 2. (A) Vertical (Embrapa) hive model.Scale bar: 1:6.5cm. (B) Horizontal ("cabocla") hives used in the comparison with the vertical hive. Scale bar: $1: 4.5 \mathrm{~cm}$. 
Hive occupation: The space occupied by each colony was estimated and later transformed into a percentage. The same procedure to guarantee the independence of data regarding the number of brood combs was used for the hive occupation. Thus, we used the monthly difference on the hive occupation in our analysis.

An independent-samples t-test with a 5\% significance level was used to compare the nest components and hive occupation of $S$. aff. postica colonies housed in the two hive models.

Management: Colony performance grades. The colonies were subjectively graded during the experimental period, based on the observations of a single observer, considering the criteria described below, and compared by using a General Linear Model with poisson residuals (Poisson GLM). Analyses were performed in R 3.3.1using the lme4 package (R Core Team, 2013).

Grade 1 - Very poor: Colony with a small number of new, young and adult workers. Brood combs with small size. Nest without laying queen and without food pots and empty upper chamber.

Grade 2 - Poor: Colony with few young and adult workers. Few new brood combs and few food pots and empty upper chamber.

Grade 3 - Average: Colony with a good number of workers, with some small brood combs and few entirely filled food pots and partially occupied upper chamber.

Grade 4 - Strong: Colony with an average number of worker bees, with some brood combs. Large food pots (honey and pollen) occupy all the space surrounding the brood combs, filling the whole base chamber and upper chamber over half occupied.

Grade 5 - Very strong: Colony with a large number of workers, several brood combs, and food pots occupy all the space surrounding the brood combs. Base and upper chambers filled.

Other parameters: The occurrence of phorid flies, cockroaches, lizards and beetles present, was registered to compare the different hive types. Dvision-Eight colonies (which reached Grade 5) were divided and the time spent in division, and the advantages and disadvantages among the two hive models were recorded at the end of the experiment.

\section{Results}

\section{Nest components and hive occupation}

Brood comb area was approximately two times larger in vertical hives $\left(5,491.6 \mathrm{~mm}^{2}\right.$ higher on average) than in the horizontal hives $(\mathrm{p}=0.001)$. There were no differences between the colonies placed in the different hive models considering all the other parameters (Table 1).

No differences were observed between the two tested hive models, regarding the percentage of occupation (horizontal: $78.17 \% \pm 13.88$ (SD) of occupation; vertical: $83.20 \% \pm 22.34(\mathrm{SD})$ of occupation; $\mathrm{t}=-0.485 ; \mathrm{DF}=48 ; \mathrm{p}=0.630$ ). Only two (40\%) of the colonies housed in the horizontal hives completely occupied the hive space, whereas four colonies $(80 \%)$ in vertical hives completely occupied the available hive space.

Table 1. Comparisons (means \pm SD) of the nest components of Scaptotrigona aff. postica colonies housed in two different hive models: Vertical and Horizontal, August/2013 to January/2014. Comparisons were made through an independent t-test.

\begin{tabular}{llllll}
\hline \multirow{2}{*}{ Nest components } & Hive & Vertical & $\mathrm{t}$ & $\mathrm{DF}$ & $\mathrm{p}$ \\
\cline { 2 - 6 } & Horizontal & $7.80 \pm 22.96$ & 0.52 & 48 & 0.602 \\
\hline Entrance tube - size* & $5.00 \pm 13.63$ & $-0.20 \pm 4.53$ & 0.16 & 48 & 0.870 \\
Entrance tube - diameter* & $0.00 \pm 4.08$ & $9.60 \pm 2.32$ & 0.54 & 28 & 0.593 \\
Number of brood combs $\dagger$ & $10.07 \pm 2.40$ & $13,348.2 \pm 4,897.55$ & -3.73 & 28 & 0.001 \\
Brood comb area $\left(\mathrm{mm}^{2}\right) \dagger$ & $7,856.6 \pm 2,905.72$ &
\end{tabular}

Data presented as: *: mean monthly differences during the whole study period; $\uparrow:$ means obtained in alternate months.

\section{Management}

The colony grades ranged from 2 to 5 for both hive models, and did not differ regarding the hive type (GLM Poisson: $\mathrm{p}=0.86$; Fig 3). Relevant differences regarding management activities when opening the hives were observed for the horizontal hive, which did not have the laths at the top of upper chamber. The brood combs were stuck to the cover of the hive, which were frequently damaged during hive inspection, and hindered the proper brood manipulation. The brood often remained stuck to the cover, forcing the inspector to remove them to avoid turning them upside down (Fig 4), a harmful process for the immature bees (see discussion). In contrast, the brood combs were fixed to the support laths of the vertical hives, not to the cover. However, there was a greater accumulation of propolis (collected tree resin) in the space between laths and the cover, leading to a greater difficulty in opening the hives, especially in strong colonies.

Eight of the ten colonies were divided, as two did not develop sufficiently to allow division. Time spent on the division process was not different between the hive types (horizontal hive: $14.35 \pm 4.88 \mathrm{~min}$; vertical hive: $8.90 \pm 1.67$ 
$\min ; \mathrm{t}=1.986 ;$ d.f. $=5 ; \mathrm{p}=0.103$ ). However, brood combs and food jars were frequently ruptured in the horizontal hives during the division procedure. Symbionts or predators were not observed in any hive during the experiment. Phorids occurred only in October/2014 and in a single horizontal hive, although not in an abundance considered to be significant for colony health.

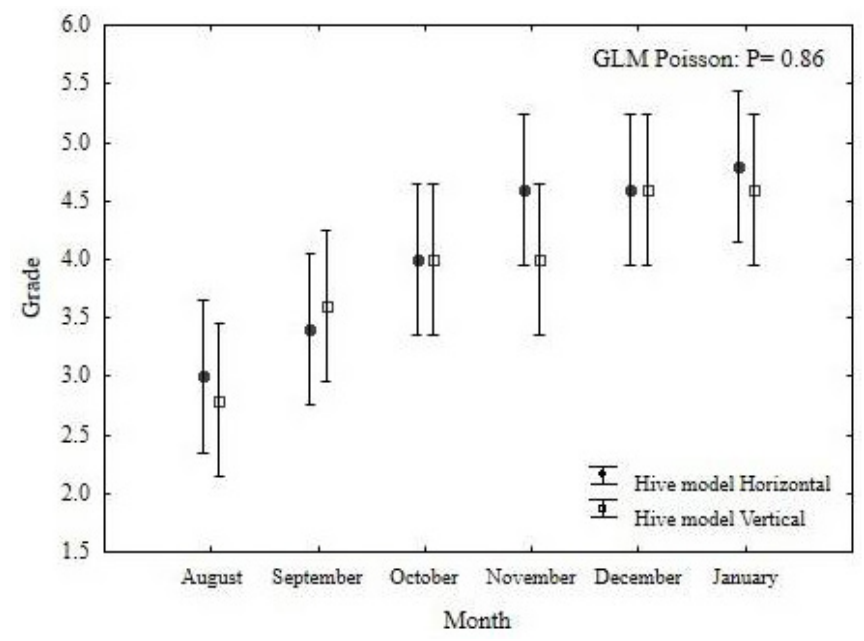

Fig 3. Variation of the subjective grades (1-very poor; 2-poor; 3-average; 4-strong; 5-very strong) of 10 Scaptotrigona aff. postica colonies housed in horizontal and vertical hives. Data presented as median and SE.

\section{Discussion}

In our study, several parameters of colony development of a meliponine species ( $S$. aff. postica) were compared between two hive models, a vertical model and a horizontal model. Our results show that the colonies developed similarly in both hive models, although there were relevant differences to qualify in the adaptation of colonies to both tested models. Although the number of brood combs was similar between the hive models, its area was about twice the size in the vertical hive relative to horizontal hives. A feasible explanation for this relies on the narrowness of the horizontal hive; this type of hive does not allow a colony of Scaptotrigona to reach its maximum size, as in order for new combs to be added, the lower one must be of a minimum size to allow the construction of the upper comb. A consequence of this reduced brood comb area is that the populations of colonies housed in horizontal hives are expected to be smaller.

A larger population (in vertical hives) guarantees an improved execution of nest maintenance activities, such as the collection of food resources and the resistance to natural enemies (Couvillon et al., 2008), which are desirable characteristics of nests aimed to be used in production. There was no difference in entrance tube length or diameter between the two hive types. Entrance tube length is perhaps more a consequence of the colony state and temporal food resource availability (seasonality), than the hive type.

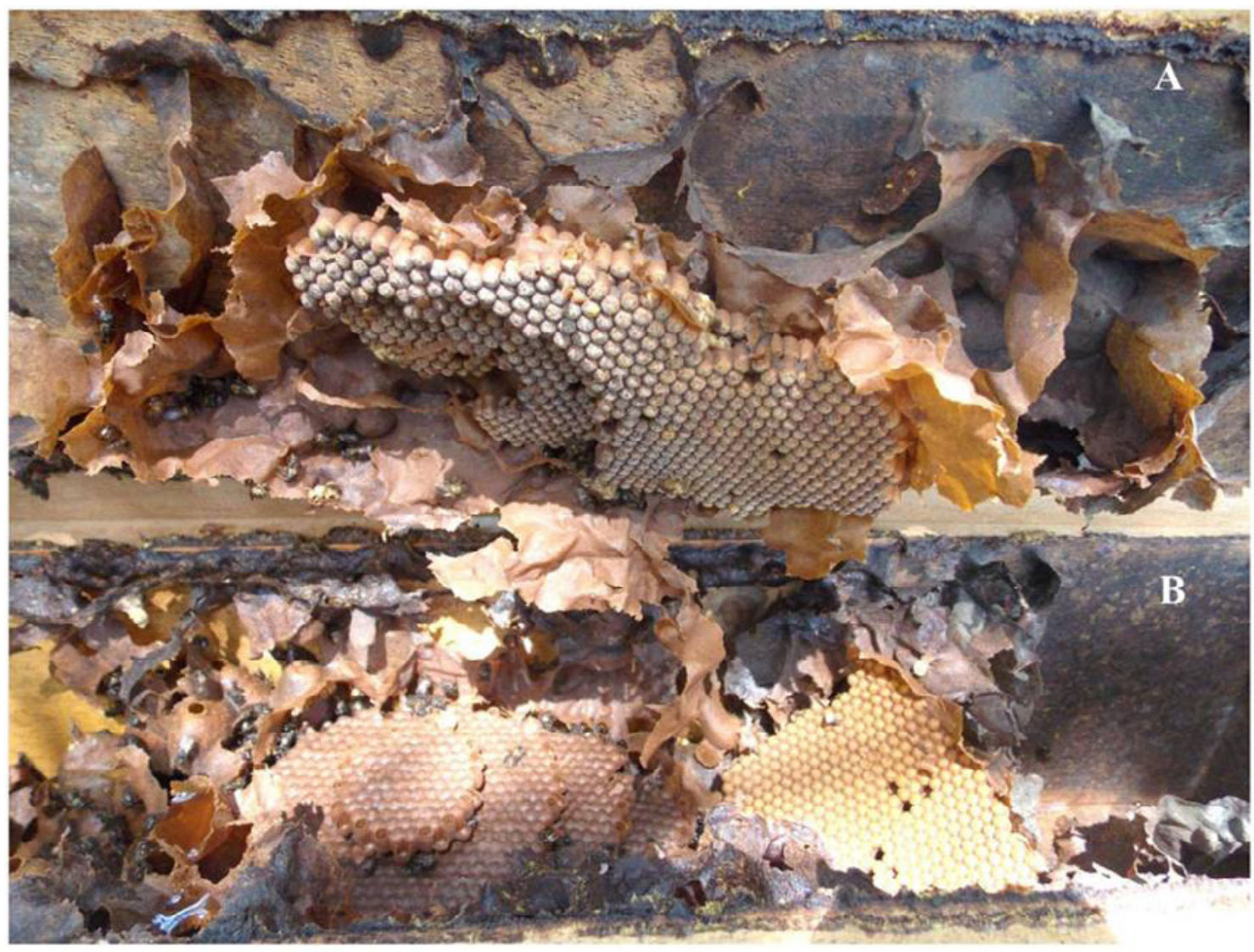

Fig 4. Brood combs of Scaptotrigona aff. postica stuck to the lid of the horizontal hive, hindering management. A-cover; B-Base nest. 
No difference in hive occupation was found between colonies in the two hive types, although there were clearly observed empty spaces in horizontal hives throughout the experiment. Empty spaces are not good for bee development, as it allows the establishment of undesirable inquilines (Nogueira-Neto, 1997), and jeopardizes nest thermoregulation (Roubik, 1989). The uniformity of the core where the immature individuals occur is important to stabilize and control the incubation temperature in stingless bee colonies (Roubik, 1989). It is likely that in the horizontal hives there was a larger effort in thermoregulation, which reduced brood production (Vollet-Neto et al., 2009), contrasting with the vertical hives, in which the nest structures entirely occupied the hive.

Differences on the adaptation of colonies in different hive models are already reported by Quezada-Euán and Gonzalez-Acereto (1994), by comparing the INPA (vertical, 14.35 L), PNN (horizontal, 14.3 L), and a traditional horizontal ("hobone", $10.06 \mathrm{~L}$ ) hive models for another meliponine species (Melipona beecheii Bennett). The authors concluded that in the traditional hive the amount of brood comb was greater than in the others models and thus, recommended a reduction in the volume of the other hive designs to ease the thermoregulation of the colonies. Although their experimental design (non-standardized hive volumes) was different from our study (i.e. equal hive volumes), the conclusion that the hives must be adequate to avoid the occurrence of empty spaces in order to ease thermoregulation is similar.

We also showed that there were differences in the ease of colony management between the different hive models; the vertical hive model facilitated the inspection and division of the colonies, contrasted to the horizontal hive model. The main problem observed when comparing the hive models was during hive opening. The absence of support laths in the horizontal hive caused the brood combs to be stuck to the lid of the hive and consequently to be turned upside down during the management. Thus, causing the death of hundreds of immature bees, as the eggs, after turned upside down, sink in the larval food and drown (Jungnickel et al., 2001). Even in brood combs with bees in pupal stages, the combs stuck in the cover leads to a greater time spent to release them.

The support laths of the vertical hive avoided the loss of new brood combs since the brood pillars (Roubik, 2006) were stuck to the laths and not to the cover. Since it is possible to manually remove each lath, the impact of the manipulation is reduced in comparison to a colony without them. However, propolis accumulation between the laths and the cover hampered opening of vertical hives, although this problem may be easily controlled by increasing the space between the laths and the cover. The large amount of propolis adhered in the colonies indicates the potential of Scaptotrigona to produce this material, another product of potentially high economic value derived from stingless bee colonies (Sawaya et al., 2009).

The subjective grades of colony strength were not statistically different among the hive models. Still, it was important to evaluate the general colony development in both hive types, being useful to identify/characterize the state of the colonies. There were no differences in division time between the colonies sheltered in the two hive types. However, division method differed between hive models. The division of the colonies in the horizontal hives was often considered more problematic than the division of colonies housed in vertical hives, where the division process was simpler. The manipulation of the brood combs and the use of a cutting tool to separate the brood combs was necessary in the horizontal hive, requiring greater technical skill. Brood comb manipulation may cause the mortality of the new individuals (e.g., by drowning in the larval food, as previously mentioned), and the rupture of the honey pots. Broken honey pots caused honey to drain to the bottom of the hive, sometimes causing the death of individuals of the colony, and attracting predators such as ants, pillaging bees, and phorid flies.

The division process was easily carried out in the vertical hive, once this hive model has subdivisions and split rods. Brood comb separation occurred naturally in the vertical hive, without major interventions, because the use of sticks between the nest and the upper nest facilitated separation and minimized damage. This result had already been reported for the stingless bee species in hives similar to the model proposed (Venturieri, 2008a). Another advantage of the vertical hives is the facilitation of honey extraction. In vertical hives, the honey is stored in a separated compartment (the super), which can be easily separated from the hive without disturbing the colony (Venturieri, 2008a).

In regard to parasites, we observed no problems with phorids, a significant natural enemy of stingless bees, in either hive models. The absence of phorids was possibly because the period during which this study was carried out was unfavorable for phorid proliferation (Oliveira et al., 2013), and due to a larger capacity of Scaptotrigona to defend itself from natural enemies. We rarely found other animals living in the hives along with the bees in this study (e.g. parasites or symbionts, common in stingless bees; Nogueira-Neto, 1997), possibly due to the short time these bees were established in these hives.

In order to enhance the stingless bee keeping practice, a standardization of procedures and methods is necessary, and the hive models are an important aspect to be considered. In our study, we showed that the vertical hive had some advantages compared with a horizontal (traditional) hive, and thus we recommend its use for housing this Scaptotrigona species. However, the keeping of colonies in horizontal hives is not necessarily impractical, since colonies still develop relatively well in this kind in hive, but when we consider that the vertical types ease the management of colonies, especially during nest divisions, the vertical hives are better from this perspective.

\section{Acknowledgments}

We would like to thank Janete Teixeira Gomes, Lorival Juracy Lucas and José Alves da Rocha for their valuable 
assistance in the field and Rodolfo Jaffé for statistical advice. We also thank Alistair Campbell for linguistic advice and two anonymous referees for insightful suggestions. We thank CAPES/EMBRAPA (15/2014) for providing grants for KLL and JCV. This research was funded by a FAPESPA grant (ICCAF: 004/2012)/CNPQ (554318/2010-5) through the Bionorte Project.

\section{References}

Contrera, F.A.L., Menezes, C. \& Venturieri, G.C. (2011). New horizons on stingless bee keeping (Apidae, Meliponini). Revista Brasileira de Zootecnia, 40 (suppl. esp.): 48-51.

Cortopassi-Laurino, M., Imperatriz-Fonseca, V.L., Roubik, D.W., Dollin, A., Heard, T., Aguilar, I., Venturieri, G.C., Eardley, C. \& Nogueira-Neto, P. (2006). Global meliponiculture: challenges and opportunities. Apidologie, 37: 275-292. doi: 10.1051/apido:2006027

Couvillon, M.J., Wenseleers, T., Imperatriz-Fonseca, V.L., Nogueira-Neto, P. \& Ratnieks, F.L.W. (2008).Comparative study in stingless bees (Meliponini) demonstrates that nest entrance size predicts traffic and defensivity. Journal of Evolutionary Biology, 21:194-201. doi: 10.1111/j.14209101.2007.01457.x

Jaffé, R., Pope N., Carvalho A.T., Maia U.M., Blochtein B., Carvalho C.A.L., Carvalho-Silze, G.A., Freitas, B.M., Menezes, C., Ribeiro, M.F., Venturieri, G.C. \& ImperatrizFonseca, V.L. (2015) Bees for development: Brazilian survey reveals how to optimize stingless beekeeping. PLOS ONE, 10(3): e0121157. doi: 10.1371/journal.pone.0121157

Jungnickel, H; Velthuis, H.H.W., Imperatriz-Fonseca, V.L. \&Morgan, E.D. (2001). Chemical properties allow stingless bees to place their eggs upright on liquid larval food. Physiological Entomology, 26: 300-305. doi: 10.1046/j.03076962.2001.00249.x

Kerr, W.E.,Carvalho, G.A. \& Nascimento, V.A. (1996). Abelha Uruçu: Biologia, Manejo e Conservação.Belo Horizonte: Fundação Acangaú, 144 p

Menezes, C., Vollet-Neto, A. \& Imperatriz-Fonseca, V.L. (2013). An advance in the in vitro rearing of stingless bee queens. Apidologie, 44: 491-500. doi: 10.1007/s13592-013-0197-6

Nogueira-Neto, P. (1997).Vida e criação de abelhas indígenas sem ferrão. São Paulo: Nogueirapis, 446 p

Oliveira, A.P.M.,Venturieri, G.C. \& Contrera, F.A.L. (2013). Body size variation, abundance and control techniques of Pseudohypocera kerteszi, a plague of stingless bee keeping. Bulletin of Insectology, 66: 203-208.

Peel, M.C., Finlayson, B.L. \& McMahon, T.A. (2007). Updated world map of the Köppen-Geiger climate classification. Hydrology and Earth System Sciences, 11:
1633-1644. doi:10.5194/hess-11-1633-2007

Portugal-Araújo, V. (1955). Colméias para abelhas sem ferrão. Angola: Boletim do Instituto de Angola, $31 \mathrm{p}$

Quezada-Euán, J.J.G. \& Gonzalez-Acereto, J. (1994). A preliminary study on the development of colonies of Melipona beecheii in traditional and rational hives. Journal of Apicultural Research, 33: 167-170. doi: 10.1080/00218839.1994.11100865

R Core Team (2013). R: A language and environment for statistical computing. R Foundation for Statistical Computing, Vienna, Austria. http://www.R-Project.org/

Reyez-González, A., Camou-Guerrero, A., Reyes-Salas, O., Argueta, A. \& Casas, A. (2014).Diversity, local knowledge and use of stingless bees (Apidae: Meliponini) in the municipality of Nocupétaro, Michoacan, Mexico. Journal of Ethnobiology and Ethnomedicine, 10: 47. doi:10.1186/1746-4269-10-47

Roubik, D.W. (1989). Ecology and Natural History of Tropical Bees. Cambridge: Cambridge University Press, $514 \mathrm{p}$

Roubik, D.W. (2006). Stingless bee nesting biology. Apidologie, 37: 124-143. doi:10.1051/apido:2006026

Sawaya, A.C.H.F., Calado, J.C.P., Santos, L.C., Marcucci, M.C., Akatsu, I.P., Soares, A.E.E., Abdelnur, P.V., Cunha, I.B.S. \& Eberlin, M.N. (2009). Composition and antioxidant activity of propolis from three species of Scaptotrigona stingless bees. Journal of Apiproduct \& ApiMedical Science, 1: 37-42. doi: 10.3896/IBRA.4.01.2.03

Sommeijer, M.J. (1999). Beekeeping with stingless bees: a new type of hive. Bee World, 80: 70-79. doi: 10.1080/0005772X.1999.11099429

Venturieri, G.C.,Raiol, V.F.O. \& Pereira, C.A.B. (2003). Avaliação da introdução da criação racional de Melipona fasciculata (Apidae: Meliponina), entre os agricultores familiares de Bragança - PA, Brasil. Biota Neotropica, 3:1-7. doi: 10.1590/S1676-06032003000200003

Venturieri, G.C. (2008a).Caixa para a criação de UruçuAmarela Melipona flavolineata Friese, 1900. Comunicado Técnico Embrapa Amazônia Oriental, 212: 1-8.

Venturieri, G.C. (2008b).Criação de abelhas indígenas sem ferrão. 2nd ed. Belém: Embrapa Amazônia Oriental, 60p

Venturieri, G.C., Alves, D.A., Villas-Bôas, J.K., Carvalho, C.A.L., Menezes, C., Vollet-Neto, A., Contrera, F.A.L., Cortopassi-Laurino, M., Nogueira-Neto, P. \& ImperatrizFonseca, V.L. (2012). Meliponicultura no Brasil: Situação Atual e Perspectivas Futuras para o Uso na Polinização Agrícola. In V.L. Imperatriz-Fonseca, D.A.L. Canhos, D.A. Alves \& A.M. Saraiva (Eds.), Polinizadores no Brasil: Contribuições e Perspectivas para a Biodiversidade, Uso Sustentável, Conservação e Serviços Ambientais (pp. 213236). São Paulo: Edusp. 
Villanueva-G, R., Roubik, D.W. \& Colli-Ucán, W. (2005). Extinction of Melipona beecheii and traditional bee keeping in the Yucatán peninsula. Bee World, 86: 35-41. doi: 10.1080/ 0005772X.2005.11099651
Vollet-Neto, A., Menezes, C., Imperatriz-Fonseca, V.L. (2009). Aquecimento de colméias de abelhas sem ferrão: vale a pena? Mensagem Doce, 103: 1-4. Retrived from: http:// www.apacame.org.br/mensagemdoce/103/artigo 4 .htm

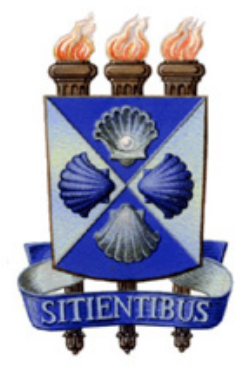

